\title{
Poplar breeding for the purpose of biomass production in short rotation periods in Germany: Problems and first findings
}

\author{
by Horst Weisgerber
}

Investigations so far on the suitability of poplars for biomass production in short rotation periods in Germany were conducted almost exclusively with clones conceived for conventional cultivation. To introduce improved plant material, a special breeding program was implemented in Hann. Münden. It takes into consideration the most important criteria of suitability for the new form of land utilization. A report is given on findings so far from the realization of this program. Comprehensive basic plant material is available for European, North American and East Asian species from the sections Aigeiros, Leuce and Tacamahaca. Interspecific crossings are being carried out mainly in order to make the best possible use of combination and heterosis effects. A period of at least 20 years is necessary to develop new cultivars with high yield performance and yield stability. First results are presented on hybrids of species which are site-tolerant, resistant and particularly fast-growing at the juvenile phase. Plans to produce multiclonal varieties, each with 5 to 10 suitable clones with the same growing rhythm are in place. Special cultivation recommendations advocate clonal mixtures for each of the most important site units and for different rotation periods of from 2 to 5,6 to 10 and more than 10 years.

Key words: poplar, breeding, biomass, short rotation
Les recherches à ce jour en Allemagne sur les possibilités d'utiliser les peupliers pour la production de biomasse au cours de courtes périodes de révolution ont été menées presqu'exclusivement avec des clones conçus pour culture conventionnelle. Pour introduire du matériel ligneux amélioré, un programme spécial d'amélioration génétique a été mis en place à Hann près de Münden. Ce programme considère l'adaptabilité au site comme étant le plus important critère pour cette nouvelle forme d'utilisation des terres. Un rapport fait état des éléments découverts à ce jour dans la réalisation du programme. Les espèces en provenance de l'Europe, de l'Amérique du Nord et de l'Assie de l'Est fournissent ensembles les éléments de base à partir des familles Aigeiros, Leuce et Tacamahaca. Des fécondations interspécifiques sont réalisées principalement pour effectuer la meilleure utilisation possible des combinaisons et des effets hétérosis. Il faut au moins vingt ans pour développer de nouveaux cultivars ayant de hauts rendements et une certaine stabilité.. Les résultats préliminaires sont tirés des hybrides d'espèces qui sont adaptés au site, résistants et particulièrement de croissance rapide au cours de la phase juvénile. Les plans de production de variétés pluriclonales, chacune étant constituée de 5 à 10 clones intéressants ayant le même rythmer de croissance, sont en place. Les recommandations spéciales de culture font état d'un mélange des clones sur chacun des plus importants sites et de différentes périodes de révolution allant de 2 à 5 , de 6 à 10 , et au delà de 10 ans.

Mots clés: peuplier, amélioration génétique, biomasse, courte révolution

\section{Objectives and Investigations}

In Germany, as in some other countries, the surplus of important agricultural produce has long been the reason for seeking new, economically reasonable and attractive possibilities for utilizing land. Chances for alternative forms of cultivation exist in particular when renewable raw materials which are utilisable in industry can be successfully incorporated into the farming enterprises' range of products. We attach considerable importance to lignicellulose in this connection.

More than 15 years of investigations have been carried out in our country on the cultivation of fast growing tree species in short rotation periods of 2 to 12 years on land previously used for agricultural purposes. However, the focus of the research is based on only a few projects. Site requirements, growing behaviour and regenerative ability of poplars and willows have been tested, technical methods of production have been tried and the ecological consequences of this form of land utilization have been assessed (Muhs 1984; Weisgerber 1984, 1990; Dimitri 1988; Makeschin et al. 1989; Bohnens 1990).

Department of Forest Tree Breeding of the Hessian, Forest Research Station and Research Institute for Fast Growing Tree Species, Hann. Münden, Germany.
More information in areas such as timber harvesting (Löffler et al. 1988; Wippermann 1991), marketing and utilising the raw material produced (Patt et al. 1989; Buchholzer 1992) or concerning the economical, agropolitical and legal framework is clearly needed before large scale recommendations on the new cultivation form can be made. Most field results of production and utilization refer almost exclusively to already known products from the conventional cultivation of fast growing tree species.

The yield potential of the most suitable poplar and willow clones under temperate climatic conditions in many countries is reported concurrently by different authors to reach values of about 15 odt $\mathrm{ha}^{-1} \mathrm{yr}^{-1}$ (for summarising information comp. Bohnens 1987; Weisgerber and Hiege 1988). As with growth performance, a strong clonal differentiation is also observed in qualitative characters. For those poplars and willows which, after cutback, develop only a few moderate branching and well growing sprouts with a low bark proportion, the outlook for a diverse utilization of the timber is promising.

\section{Opportunities for Breeding}

Yield results obtained so far appear inadequate both from a quantitative and a qualitative point of view. The existing genetic potential is not being sufficiently exploited. Most of the clones named in the literature were 
originally bred for considerably longer rotation periods (15 years or more). The growing rhythm of this plant material does not meet the requirements of high biomass production recurring at short intervals.

Intensified breeding is needed to generate vigorous and high yielding clones on as broad a genetic basis as possible. Bohnens (1987) listed the most important characteristics of plants suited to short rotation:

- site tolerance; reliable rooting;

- good utilization of the growing period, high net photosynthetic rate;

- low water and nutrient demand in relation to the biomass produced;

- optimal growth development during the juvenile phase defined as rotation period;

- high use of photosynthetic material for secondary growth in thickness;

- narrow, compact crowns, relatively small proportion of branches, acute branch orientation for the best possible use of light in the dense stands;

- low phototropic sensitivity, competition tolerance;

- resistance to biotic and abiotic damages;

- good regenerative ability by resprouting or root suckers, remaining reliable for several rotation periods;

- easy and cheap propagation;

- advantageous wood properties suitable for the intended purpose.

These criteria necessitate new breeding programs in order to promote fast growth in the early stages of development and good regenerative ability. It must be noted, however, that only vague ideas exist as yet about the optimal combination of characters. This is especially the case with wood properties due to greatly varying requirements. Stable and well defined breeding goals are thus difficult to develop.

\section{Breeding Work in Hann. Münden \\ Test material and Procedures}

Research work with poplars at our institute is based on extensive plant material with a broad genetic range. Besides numerous populations, more than 800 clones are available, mainly from the sections Aigeiros, Leuce and Tacamahaca. The collections are being enlarged considerably with selections from some east Asian balsam and white poplars and also aspen. The multiplicity of varieties of the species involved offers good pre-conditions for controlled crossings and for advanced selection measures among the progenies. New combinations of characteristics and heterosis effects can be utilised effectively.

Controlled pollinations take place with black and balsam poplars in the populetums. For intra- and interspecific aspen combinations a special greenhouse is available. As far as East Asian species are concerned, clone collections built up with Chinese-German cooperation are included in the investigations (Weisgerber 1991).

The following poplar species are included in the crossing programs (Table 1).

We began conducting the crossing work in 1983. Until now, the individual species were considered principally or only sporadically. The progenies are first tested in the nursery for resistance to diseases, especially to the pathogen of
Table 1. Poplar species included in the crossing programs.

\begin{tabular}{|c|c|c|}
\hline section Aigeiros & section Leuce & section Tacamahaca \\
\hline $\begin{array}{l}\text { P. deltoides Marsh. } \\
P \text {. nigra L. }\end{array}$ & $\begin{array}{l}\text { P. adenopoda Maxim. } \\
P . \text { alba } \mathrm{L} \text {. } \\
P . \times \text { canescens } \text { Smith } \\
P . \text { davidiana } \text { Dode } \\
P . \text { glandulosa } \text { Uyeki } \\
P . \text { grandidentata } \text { Mich. } \\
P . \times \text { hopeiensis } \text { Hu et Chow } \\
P . \times \text { tomentos } \text { Carr. } \\
P . \text { tremula } \text { L. } \\
P . \text { tremuloides } \text { Mich. }\end{array}$ & $\begin{array}{l}\text { P. cathayana } \text { Rheder } \\
\text { P. maximowiczii Henry } \\
\text { P. purdomii Rheder } \\
\text { P. simonii Carr. } \\
\text { P. szechuanica Schneid. } \\
\text { P. trichocarpa Torr. \& Gray } \\
\text { P. yunnanensis Dode }\end{array}$ \\
\hline
\end{tabular}

poplar canker, Xanthomonas populi. This early test method is done by means of artificial inoculation. The early testing by its quick elimination of susceptible clones has been successful at our institute (Kechel 1984; Janssen 1991). The resistant and best-growing progenies are initially cloned for further multisite tests of performance and quality.

As a rule at least 6 to 8 years are needed for the measures described, from the time crossing takes place until the selected trees are propagated for the field test to follow. At least 20 years are needed for the development of new varieties suited for practical use.

\section{Results}

Crossings completed to-date have led to very disparate results depending on the particular partners used. Our main interest in the interspecific crosses was to achieve as favourable combination and heterosis effects as possible. Crossings between species with known or expected high incompatibility to each other were not completed. Within the section Leuce, all crossings in which $P$. tremula was used as a partner were successful. When this species was combined with $P$. adenopoda, $P$. alba, $P$. davidiana, $P$. glandulosa, $P$. grandidentata, $P$. tomentosa and $P$. tremuloides, good seed yields and in most cases also large numbers of seedlings were obtained. In the section Tacamahaca good crossing results were achieved in particular with $P$. maximowiczii, whereby $P$. trichocarpa proved once more - as in earlier investigations - a suitable partner. The $P$. szechuanica-combinations, on the other hand, resulted mostly in too small seed yields. Here too, however, the hybrids with $P$. trichocarpa seemed promising and were therefore included in further breeding work. Results obtained for the first new varieties developed include their growth pattern on a trial plot in Westphalia. Some $P$. maximowiczii $\times P$. trichocarpa-hybrids distinguish themselves here by their fast growth. After four vegetation periods, the five best clones of these progenies out-performed by an average of $20 \%$ in dry matter production the $P$. trichocarpa $\times P$. deltoides-clones 'Beaupré', 'Raspalje' and 'Unal' which are known in Germany to be particularly fast growing. Compared with the $P$. nigra $\times P$. maximowicziiclones, 'Max 1' and 'Max 2', which are also regarded as high yielding, there was an average superiority of $36 \%$; compared with the $P$. trichocarpa-clones 'Fritzi Pauley' and 'Columbia River' it was $110 \%$. The performance potential of these five balsam poplar hybrids has been confirmed on two trial plots with different climatic and site conditions. They possess, therefore, characteristics which 
fulfill some of the most important breeding aims: site tolerance, resistance to disease and yield improvement in the juvenile phase. We still need information about important qualitative features such as regenerative ability, branching or wood properties. A longer testing period must be expected for the progenies from Leuce-crossings. This is especially the case with aspen hybrids. Because their intensive growing phase starts later than that of black and balsam poplars, they come into consideration primarily for cultivation forms with a longer rotation period (more than 10 years).

\section{Perspectives}

After the successful completion of resistance examinations we have entered the phase of field testing of a large number of other hybrids. We assume that many of these "candidates' will prove suitable for practical cultivation. If one estimates a genetic gain of 20 to $30 \%$ for the trait growth vigour for the new varieties, as compared to the plant material deployed today, then average yields of between 20 and $30 \mathrm{odt} / \mathrm{ha} /$ year could be achieved under favourable site conditions. Clones with proven suitability are grouped according to their respective growth rhythm and according to other traits that influence competition behaviour (branching, crown architecture). We intend to build up in this way multiclonal varieties consisting of 5 to 10 clones each, in order to guarantee as broad a genetic basis as possible to ensure yield stability. In addition, cultivation recommendations should be compiled as soon as possible, advocating one, or better several, of these clonal mixtures for each of the site units under consideration and for different rotation periods of between 2 and 5, 6 and 10, and more than 10 years.

\section{References}

Bohnens, J. 1987. Stand und Perspektiven des Anbaus schnellwachsender Baumarten im Kurzumtrieb in Europa. Holzzucht 41: 11-15.

Bohnens, J. 1990. Breeding aspects of biomass production with fast growing tree species in short rotation periods. In: Grassi, G., G. Gosse, G. dos Santos, (eds.): Biomass for Energy and Industry. 5th E.C. Conference, Lisbon, Portugal, Oct. 9-13, 1989; London and New York: Elsevier Applied Science, 1176-1182.

Buchholzer, P. 1992. Eignung von Pappelindustrieholz unterschiedlicher Klone, Altersstufen und Standorte für die
Spanplattenherstellung. Holz-Zentralblatt 118: 165, 168, 280, 282.

Dimitri, L. 1988. Bewirtschaftung schnellwachsender Baumarten im Kurzumtrieb zur Energiegewinnung. Schriften Forschungsinst. f. schnellwachsende Baumarten, Hann. Münden, Bd. 4.

Janssen, A. 1991. Entwicklung von Frühtestmethoden in der Invitro-Phase zur Resistenzprüfung von Pappelklonen gegenüber dem Erreger des Pappelkrebses, Xanthomonas populi subsp. populi (Ridé) Ridé und Ridé. Schriften Forschungsinst. f. schnellwachsende Baumarten, Hann. Münden, Bd. 7.

Kechel, H.G. 1984. Untersuchungen über die Resistenz von Pappeln gegenüber dem Erreger des Pappelkrebses, Xanthomonas populi subsp. populi (Ridé) Ridé und Ridé. Schriften Forschungsinst. f. schnellwachsende Baumarten, Hann. Münden, Bd. 3.

Löffler, H., W. Patzak, H. Dürrstein. 1988. Ernte von Kurzumtriebsplantagen. Forstl. Forschungsberichte München 90: 26-57.

Makeschin, F., K.E. Rehfuess, I. Rüsch, R. Schörry. 1989. Anbau von Pappeln und Weiden im Kurzumtrieb auf ehemaligem Acker: Standörtliche Voraussetzungen, Nährstoffversorgung, Wuchsleistung und bodenökologische Auswirkungen. Forstw. Cbl. 108: 125-143.

Muhs, H.-J. 1984. Schnellwachsende Baumarten im Kurzumtrieb: Produktion, züchterische, ökologische, forst- und agrarpolitische Aspekte. Forstarchiv 55: 171-174.

Patt, R., O. Kordsachia, N. Mix. 1989. Über die Eignung von Pappelholz zur Zellstoffherstellung nach dem ASAM-Verfahren. Holz-Zentralblatt 115: 21-22, 26.

Weisgerber, H. 1984. Klonvergleichsprüfungen bei Schwarzund Balsampappeln im Kurzumtrieb. Holzzucht 38: 21-25.

Weisgerber, H. 1990. Fast growing trees in short rotation periods on agricultural land. Present state knowledge and perceptions on the future. In: D. Werner, P. Müller (eds.): Fast Growing Trees and Nitrogen Fixing Trees. pp. 47-56. Intern. Conference, Marburg, Germany, Oct. 8-12, 1989.

Weisgerber, H. 1991. Forstliche Verhältnisse in der Volksrepublik China. Erste Ergebnisse deutsch-chinesischer Zusammenarbeit zur Wiederbewaldung des Landes. HolzZentralblatt 117: 1696-1698, 1716-1718.

Weisgerber, H., W. Hiege. 1988. Selection and breeding. In: F.C. Hummel, W. Palz, G. Grassi. (eds.): Biomass Forestry in Europe: A Strategy for the Future. pp. 141-168. Energy from Biomass 3. Elsevier Applied Science, London and New York. Wippermann, J. 1991. Nutzung von Kurzumtriebsflächen. Forstarchiv 62: 26-28. 